\title{
Jenis Tanaman Berguna Bagi Suku Dani di Lembah Baliem, Papua
}

\author{
The Useful Plants of Dani Ethnic Groups at The Baliem Valley of Papua
}

\author{
Agustina Y.S. Arobaya ${ }^{1}$, Freddy Pattiselanno ${ }^{2 *}$ \\ ${ }^{1}$ Herbarium Manokwariense, Pusat Penelitian Keanekaragaman Hayati (PPKH) Universitas Negeri Papua \\ ${ }^{2}$ Laboratorium Produksi Ternak FakultasPeternakanPerikanan \& Ilmu Kelautan (FPPK) Universitas Negeri \\ Papua, E-mail: freddy_pattiselanno@unipa.ac.id *Penulis untuk korespondensi
}

Dua studi lapangan yang terpisah telah dilakukan di Lembah Baliem (138030'-139030' BT dan $34^{\circ} 0^{\prime}-42^{0} 0^{\prime}$ LS) Papua untuk mengidentifikasi jenis-jenis tanaman berguna bagi suku Dani yang hidup di lembah tersebut. Studi lapangan pertama dilakukan selama lima bulan (Maret - Juli 1994) di Mume-Kuyawage dan Mapnduma. Studi ini merupakan bagian dari program kajian ekologi Taman Nasional Lorentz dari WWF. Studi kedua merupakan observasi singkat (21 - 26 Mei 2005) di sekitar kota Wamena yakni Kumima, Siapkosi, Napua, Sinakma, Pisugi, Wanima, Sunili, Tulem dan Woma. Studi ini bagian dari penelitian usaha peternakan tradisional kerjasama Dinas Peternakan Kabupaten Jayawijaya, International Potato Centre (CIP) Bogor and South Australian Research and Development Institute (SARDI). Investigasi langsung dilakukan diikuti dengan wawancara semi-struktural untuk menghimpun informasi tentang jenis tanaman berguna yang biasanya dimanfaatkan oleh suku Dani.

Kedua studi lapangan ini berhasil mengidentifikasi minimal 35 jenis tanaman berguna yang dimanfaatkan suku Dani untuk berbagai keperluan, contohnya untuk bahan konstruksi, kayu bakar, pangan, peralatan dapur dari berburu serta sebagai ornament budaya atau ritual tertentu (Tabel 1).

Pemanfaatan jenis tanaman sebagai bahan bangunan sangat bervariasi diantara suku-suku di Papua. Tujuh jenis tanaman diidentifikasi sebagai bahan bangunan yang umum digunakan oleh suku Dani. Misalnya untuk bahan bangunan banyak digunakan Podocarpus papuana sebagai panel dinding bagian dalam, sedangkan bagian luar terbuat dari Araucaria cunninghamii, Paraserianthes faltacaria dan beberapa jenis kayu keras lainnya. Imperata cylindrica atau daun palem
(Calamus sp.) dimanfaatkan baik untuk atap rumah maupun kandang ternak babi. Sedikit berbeda dengan suku-suku yang mendiami wilayah pesisir, misalnya kelompok etnik di Pulau Rumberpon memanfaatkan kelompok tanaman bakau sebagai bahan konstruksi rumah mereka (Leonard et al., 2003). Jenis yang sama digunakan secara umum oleh suku Dani Paraserianthes falcataria juga digunakan oleh suku Wondama di Desa Tandia di Wasior sebagai bahan konstruksi(Worabai et al., 2001).

Pemanfaatan jenis tanaman tertentu sebagai kayu bakar merupakan hal yang umum dilakukan oleh kelompok masyarakat yang mendiami daerah sekitar hutan. Dalam penelitian ini ditemukan 17 jenis tanaman digunakan secara luas oleh suku Dani sebagai sumber kayu bakar. Studi Peday (2004) di daerah dataran tinggi di Jayawijaya berhasil mengidentifikasi jenis tanaman lain yang digunakan oleh suku Dani sebagai kayu bakar. Hasil penelitian ini menunjukan bahwa jenis-jenis tanaman untuk kayu bakar oleh masyarakat Dani masih lebih rendah dibanding masyarakat di Timor Barat, yang memanfaatkan kurang lebih 21 jenis tanaman (Pulunggono, 1999).

Studi yang dilakukan Rachman et al., (1996) di enam desa (Mukoko, Wouma, Walesi, Hubkosi, Honelama dan Kosilapok) di kota Wamena mengungkapkan bahwa jenis tanaman tertentu umumnya digunakan sebagai kayu bakar antara lain Bischofia javanica, Casuarina sp., Greviela papuana dan Paraserianthes faltacaria. Jenis lainnya adalah Phyllocladus hypophyllus, Papuacedrus papuanus, Dendrocnide peltata, Podocarpus amarus, Podocarpus neriifolius, Elaeocarpus sp, dan Araucaria klinki secara teratur dimanfaatkan sebagai kayu bakar di daerah dataran tinggi Wamena. 
Tabel 1. Jenis tanaman yang dimanfaatkan suku Dani dalam aktivitas hariannya

\begin{tabular}{|c|c|c|}
\hline Species & Nama Lokal & Pemanfaatan \\
\hline Acalypha amentacea & Lesane & $\begin{array}{l}\text { Daun kering untuk menggulung tembakau, ranting keras untuk } \\
\text { kayu bakar, kulit elastis untuk keranjang dan bahan rajutan } \\
\text { untuk tas serta bahan untuk pakaian wanita }\end{array}$ \\
\hline Alpinia brevituba & Jewi & Bumbu mempunyai aroma spesial seperti jahe \\
\hline Araucaria cunninghamii & Sien & Bahan konstruksi, kayu bakar dan peralatan berburu \\
\hline Alyxia floribunda & Ilak-ilak & Kulit digunakan untuk bahan rajutan tas wanita \\
\hline Baeckea frustescens & Wileh-wileh & Bahan kayu bakar \\
\hline Bischofia javanica & Pum & Bahan kayu bakar yang baik \\
\hline Calamus prattianus & Mul & $\begin{array}{l}\text { Bahan pembuat tali, keranjang, peralatan pertanian dan alat } \\
\text { berburu (panah dan busur) }\end{array}$ \\
\hline Castanopis acuminatissima & Heye & $\begin{array}{l}\text { Buahnya dapat dimakan, kayu untuk konstruksi, pagar dan kayu } \\
\text { bakar }\end{array}$ \\
\hline Casuarina sp. & Kasuari & Bahan kayu bakar yang baik \\
\hline Cordyline terminalis & Jabe & $\begin{array}{l}\text { Dahan dan ranting untuk kayu bakar, dan daun digunakan dalam } \\
\text { tarian upacara adat }\end{array}$ \\
\hline Dacydium elatum & Wapi & Kayu bakar \\
\hline Dawsonia beccari & Wurigi & Dahan keras digunakan untuk bahan rajutan rok wanita \\
\hline Eleocharis dulchis & Sali & Bahan rok wanita \\
\hline Ficus aderosperma & Hule & $\begin{array}{l}\text { Kayu kering digunakan untuk pagar dan kayu bakar, sedangkan } \\
\text { kulit kayu sebagai bahan rok wanita }\end{array}$ \\
\hline Greviela papuana & Wip & Kayu bakar \\
\hline Helichrysum bracteatum & Bunga Kurulu & Bunga dengan nilai jual tinggi \\
\hline Imperata cylindrica & Alang-alang & Bahan atap rumah dan kandang ternak \\
\hline Ipomoea batatas & Hipere & Sumber makanan utama suku Dani \\
\hline Lagenaria siceraria & Sika / holim & $\begin{array}{l}\text { Buahnya dikonsumsi, bunga kering berbentuk seperti botol } \\
\text { digunakan sebagai tempat menyimpan air dan darah dalam } \\
\text { upacara adat. Buah yang berbentuk panjang dan lurus digunakan } \\
\text { sebagai "koteka" pelindung penis }\end{array}$ \\
\hline Metrosideros pullei & Selon & $\begin{array}{l}\text { Kayu keras yang digunakan sebagai bahan konstruksi, pagar, } \\
\text { alat penggali, tombak dan kayu bakar }\end{array}$ \\
\hline Mussaenda reindwardtiana & Pit-pit engka & $\begin{array}{l}\text { Daun muda digunakan sebagai bahan alas "noken" keranjang } \\
\text { yang sering digunakan untuk memikul barang. }\end{array}$ \\
\hline Pandanus conoideus & Saik-eken & $\begin{array}{l}\text { Minyak digunakan untuk memasak bahan makanan dan } \\
\text { ampasnya merupakan pakan ternak babi }\end{array}$ \\
\hline Pandanus julianettii & Saluke & $\begin{array}{l}\text { Buahnya dikonsumsi sedangkan daun biasanya digunakan } \\
\text { sebagai payung dan bahan atap pondok di hutan }\end{array}$ \\
\hline Pandanus pectinatus & Saim & Daun menggantikan fungsi payung dan sebagai bahan tikar \\
\hline Paraserianthes faltacaria & Wiki & $\begin{array}{l}\text { Terkadang digunakan sebagai bahan pagar tetapi umumnya } \\
\text { dimanfaatkan untuk kayu bakar }\end{array}$ \\
\hline Piper gibbilimbum & Yelika & Biasanya dipakai sebagai pengganti piring atau gelas \\
\hline Pittosporum ramiflorum & Munika & $\begin{array}{l}\text { Kayu dimanfaatkan sebagai kayu bakar dan bijinya dipakai } \\
\text { anak-anak untuk bermain perang-perangan }\end{array}$ \\
\hline Podocarpus papuana & Farahab & Kayu bakar dan komponen konstruksi \\
\hline Setaria palmifolia & Sowa & $\begin{array}{l}\text { Dauan dikonsumsi, dimasak dengan cara "bakar batu" - cara } \\
\text { tradisional memasak dengan batu yang panas }\end{array}$ \\
\hline Wendlandia paniculata & Sugun & $\begin{array}{l}\text { Dahan dan ranting kering digunakan sebagai pagar dan kayu } \\
\text { bakar }\end{array}$ \\
\hline Wikstroemia venosa & Henawun & $\begin{array}{l}\text { Kulit yang elastis digunakan sebagai tali untuk merajut } \\
\text { keranjang dan bahan rok wanita }\end{array}$ \\
\hline
\end{tabular}


Kelompok etnik yang mendiami wilayah pesisir Papua, mengambil keuntungan dari jenis bakau yang penyebaran dan kelimpahannya cukup tinggi, misalnya kelompok masyarakat di Supiori Selatan di Biak Numfor yang memanfaatkan jenis mangrove sebagai kayu bakar (Mamoribo et $a l ., 2003)$. Hal yang sama juga ditemukan pada suku Inanwatan di Sorong, memanfaatkan beberapa jenis bakau seperti Ceriops decandra, Avicennia sp., Rhizophora sp., dan Sonneratia sp. sebagai sumber energi dan kayu bakar (Prayitno et al., 2002). Kelompok masyarakat Senebuay di Pulau Rumberpon memanfaatkan delapan jenis bakau untuk berbagai tujuan antara lain kayu bakar, obat-obatan dan peralatan berburu (Leonard, et al., 2003).

Jika ditinjau menurut aspek ketahanan pangan, meskipun tidak terlalu banyak yang diungkap selama pengamatan, beberapa jenis tanaman berhasil teridentifikasi dimanfaatkan sebagai sumber bahan pangan secara khusus bagian buahnya antara lain: Ipomoea batatas, Lagenaria siceraria, dan Pandanus julianettii. Terbatasnya waktu pengamatan di lapangan mempengaruhi jumlah jenis yang dimanfaatkan oleh suku Dani sebagai sumber pangan. Hasil ini lebih rendah dibandingkan temuan di suku Wondama di Wasior, yang memanfaatkan 24 species tanaman sebagai sumber pangan mereka Worabai et al., (2001).

Penelitian ini juga berhasil mengidentifikasi sembilan jenis tanaman yang dimanfaatkan untuk tujuan sosial budaya misalnya sebagai ornament dalam kegiatan ritual budaya setempat. Pemanfaatan jenis tanaman untuk tujuan sosial budaya juga dilakukan oleh kelompok etnik di wilayah pesisir, misalnya di Kepala Burung, empat species mangrove dimanfaatkan untuk tujuan sosial dan budaya oleh kelompok etnik lokal di Senebuay, Pulau Rumberpon (Leonard et al., 2003). Di hutan dataran rendah Bayeda di Teluk Arguni, dua species palem dimanfaatkan untuk ritual budaya oleh komunitas masyarakat setempat (Nega et al., 2003).

Studi ini hanya sedikit menemukan jenis tanaman obat tradisional, karena memang fokus pengamatan lebih banyak tertuju pada jenis tanaman yang digunakan sehari-hari seperti kayu bakar dan bahan konstruksi.
Namun kami masih percaya bahwa suku Dani, seperti suku-suku asli Papua lainnya, masih mempunyai tingkat ketergantungan yang tinggi pada jenis tanaman tertentu sebagai sumber obat tradisional. Walaupun pada saat ini pelayanan medis modern telah disediakan oleh pemerintah maupun swasta.

Pendapat ini sejalan dengan hasil kajiankajian di beberapa daerah lain di Papua. Misalnya di Pulau Mansinam Manokwari, Hamzah et al., (2003) mengidentifikasi 25 jenis tanaman obat, 19 diantaranya obat untuk mengobati penyakit manusia. Bagian tanaman yang banyak dimanfaatkan yaitu daun (kurang lebih 18 jenis). Hal yang sama dijumpai pada suku Wiekhaya di Arso, Jayapura yang memanfaatkan daun dari 21 jenis tanaman (dari 41 jenis) digunakan sebagai obat tradisional (Suebu etal., 2002). Suku Maibrat di Sorong menggunakan kurang lebih 40 jenis tanaman obat (30 famili) dalam kehidupan sehari-hari mereka (Howay et al., 2003). Menurut Pulunggono (1999) 22 jenis tanaman obat (13 famili) umumnya merupakan produk hasil hutan yang dimanfaatkan sebagai obat-obatan tradisional masyarakat Amarasi di Kupang, Mollo dan Amanatun di Timor Tengah Selatan. Jenis tersebut masih lebih sedikit jika dibandingkan penggunaan tanaman obat di Sumatera Utara (Simbolon, 1994).

Berdasarkan pengamatan di lapangan, wawancara serta hasil penelusuran sejumlah pustaka yang relevan, diketahui bahwa jenis tertentu bukan merupakan tanaman asli Lembah Baliem, tetapi sekarang tumbuh dan menyebar di sekitar lokasi penelitian. Beberapa jenis yang dicatat oleh Wiriadinata et al., (1992) seperti Acalypha amentacea yang berasal dari wilayah tropis di Amerika diintroduksi ke Lembah Baliem oleh misionaris, dan Helichrysum bracteatum diintroduksi ke Tiom sekitar tahun 1966, dan saat ini umumnya ditemukan menyebar di beberapa tempat di sekitar lembah. Selain itu Solanum sp dan Passiflora indica juga merupakan species introduksi yang dilakukan oleh misionaris dan dikenal sebagai jenis buah yang dikonsumsi sampai dengan saat ini (Jonias Kogoya pers.comm, 2006). 


\section{Ucapan Terima Kasih}

Pak Luther dan Satya banyak
menghabiskan waktu untuk membantu mengamati, mewawancarai serta bekerja sama dengan kami selama melakukan kunjungan lapang ke Lembah Baliem. Penghargaan patut pula disampaikan kepada Yot Murip untuk menemani selama pengamatan di Kuyawage, Pak Essau Renmaur and Pak Untung Ginting sebagai counterparts selama di lapang. Tanpa dukungan dana dari WWF Irian Jaya Program (sekarang ini Bio-region Sahul for Papua Program) dan CIP-SARDI Pig Project di Lembah Baliem informasi ini tidak dapat kami himpun dengan baik.

\section{Daftar Pustaka}

Hamzah, P., Kesaulija, E.M. dan Rahawarin, Y. 2003. Pemanfaatan Tumbuhan Obat Tradisional oleh Masyarakat Pulau Mansinam Kabupaten Manokwari. Beccariana 5 (2): 52-60.

Howay, M., Sinaga, N.I. and Kesaulija, E.M. 2003. Utilization of plants as traditional medicines by Maibrat Tribe in Sorong. Beccariana 5 (1): 24-34.

Leonard, D., Wanggai, J. and Manusawai, J. 2003. The use of plants from mangrove forest by local people in Senebuay Village, District of Rumberpon Manokwari. Beccariana 5 (2): 97-108.

Mamoribo, S., Arwam, C.Y.H. and Yusuf, A. 2003. Utilization of mangrove by the community in Royori Kampong of South Supiori, Biak Numfor. Beccariana 5 (1): 43-51.

Nega, L.B., Wasaraka, A.R. and Heatubun, C.D. 2003. Exploration of palm species in the lowland forest of Bayeda District, Arguni Bay. Beccariana 5 (2): 67-81.
Peday, H.F.Z. 2004. Analysis of vegetation of commercial trees in Ibele Village, District of Hubikosi Jayawijaya, the buffer zone of Lorentz National Park. Beccariana 6: 33-39.

Pulunggono, H.B. 1999. The ethnobotanical studies of people in Amarasi of Kupang, Mollo and Amanatun of South Central Timor, West Timor, Indonesia. Media Konservasi 6: 27-38.

Pulunggono, H.B. 2002. Forest use and conservation by local communities in Western Timor, Indonesia. Media Konservasi III: 81-90.

Prayitno, S.W.M., Manusawai, J. dan Witjaksono, W. 2002. Pemanfaatan Tumbuhan Mangrove bagi Kehidupan Masyarakat Suku Inanwatan di Kabupaten Sorong. Beccariana 4 (2): 79-92.

Rachman, E., Mahfudz and Kuswandi, R. 1996. Research on species trial and consumption rate of fuel wood in Community Forest Development Program in Wamena. Bull. Penelitian Kehutanan 1 (1): 41-50.

Simbolon, H. 1994. Ethnobotany of people around the Dolok Sibuali-Buali Nature Reserve Area, North Sumatera, Indonesia. Tropics 4: 69-78.

Suebu, J., Manusawai, J. and Ramandey, Y. 2002. Potensi Tumbuhan Berkasiat Obat pada Masyarakat Suku Wie-Khaya Kecamatan Arso Kabupaten Jayapura. Beccariana 4 (2): 68-78.

Wiriadinata, H., Irawati, R.E., Nasution, A.T., Sunarto and Roemantyo. 1992. Plants and flowers of Baliem Valley Jayawijaya. Research and Development Centre for Biology Indonesia Institute of Sciences.

Worabai, S., Kesaulija, E.M. dan Maturbongs, R.A. 2001. Pemanfaatan jenis tumbuhan pohon oleh suku Wondama di desa Tandia, Wasior Kabupaten Manokwari. Beccariana 3 (2): 19-30. 